\title{
Pengaruh Leverage dan Ukuran Perusaaan Pada Nilai Perusahaan
}

\author{
Kevin Hestia Gigih Anugerah ${ }^{1}$ \\ I Ketut Suryanawa ${ }^{2}$
${ }^{1,2}$ Fakultas Ekonomi dan Bisnis Universitas Udayana (Unud), Bali, Indonesia e-mail: hestiakevin@gmail.com

\begin{abstract}
ABSTRAK
Tujuan utama perusahaan adalah untuk memaksimalkan kemakmuran stakeholder, hal ini dapat dicapai dengan memaksimalkan nilai perusahaan. Tetapi terkadang perusahaan gagal untuk meningkatkan nilai perusahaan, yang salah satu penyebabnya adalah kurang cermatnya perusahaan dalam mengaplikasikan faktor-faktor yang mempengaruhi nilai perusahaan. Tujuan penelitian ini adalah untuk mengetahui pengaruh leverage dan ukuran perusahaan pada nilai perusahaan sektor farmasi di BEI. Populasi dalam penelitian ini adalah perusahaan sektor farmasi yang terdaftar di BEI pada periode 2013-2016 yaitu berjumlah 10 perusahaan. Teknik penentuan sampel yang digunakan adalah purposive sampling, maka sampel yang didapatkan adalah 8 perusahaan. Metode pengumpulan data yang digunakan dalam penelitian ini adalah obsevasi non partisipan. Sumber data dalam penelitian ini adalah data sekunder yang diperoleh dari www.idx.co.id. Teknik analisis data yang digunakan adalah regresi linier berganda. Berdasarkan hasil analisis menunjukkan leverage berpengaruh negatif dan signifikan pada nilai perusahaan, dan ukuran perusahaan berpengaruh positif dan signifikan pada nilai perusahaan.
\end{abstract}

Kata kunci: Nilai perusahaan, leverage, ukuran perusahaan

\begin{abstract}
To maximize the welfare of stakeholders, can be achieved by maximizing the value of the company. But sometimes companies fail to increase that, because of less conscientious in applying factors influencing the value of enterprise. The purpose of this study was to determine the effect of leverage and the size of the company in the pharmaceutical sector enterprise value on the Stock Exchange. The population in this study is pharmaceutical sector companies listed on the Stock Exchange in the period 2013-2016 which amounted to 10 companies. Sampling technique used was purposive sampling, the samples obtained are 8 companies. Data collection methods used is non-participant observation. Sources of data is secondary data obtained from www.idx.co.id. The data analysis technique used is multiple linear regression. Based on the analysis shows leverage significant negative effect, and the size of the company and significant positive effect on the value of the company.
\end{abstract}

Keywords: Enterprise value, leverage, company size

\section{PENDAHULUAN}

Bertambahnya jumlah perusahaan dalam industri telah menciptakan suatu persaingan yang semakin ketat antar perusahaan. Persaingan dalam industri membuat setiap perusahaan semakin meningkatkan kinerja agar dapat mencapai tujuannya. Umumnya suatu perusahaan akan selalu berusaha untuk mencapai 
tujuannya, baik tujuan jangka panjang yaitu mampu meningkatkan nilai perusahaan dan mensejahterakan pemegang saham, maupun tujuan jangka pendeknya misalkan memaksimalkan laba perusahaan dengan sumber daya yang dimiliki. Perusahaan go public akan selalu berusaha untuk meningkatkan nilai perusahaannya guna menarik perhatian investor (Pramana \& Mustanda, 2016).

Nilai perusahaan dapat tercermin pada harga pasar saham suatu perusahaan, dimana harga saham memiliki hubungan yang positif dengan nilai perusahaan. Semakin tinggi harga pasar saham suatu perusahaan maka nilai perusahaan juga akan meningkat. Harga saham yang tinggi membuat ketertarikan investor akan semakin besar, karena nilai perusahaan yang tinggi mengindikasikan bahwa tingkat kemakmuran yang tinggi dari para pemegang saham dalam suatu perusahaan (Wijaya \& Sedana, 2015). Nilai perusahaan penting untuk dimaksimalkan karena memaksimalkan nilai perusahan berarti memaksimalkan kemakmuran pemegang saham yang merupakan tujuan utama perusahaan.

Nilai perusahaan merupakan persepsi seorang investor terhadap perusahaan itu sendiri. Investor dapat mempergunakan nilai perusahaan sebagai dasar untuk menilai kinerja perusahaan di masa yang akan datang, dimana nilai perusahaan ini sering dikaitkan dengan harga saham. Investor akan memperoleh keuntungan apabila harga saham dalam suatu perusahaan tinggi. Harga saham suatu perusahaan yang tinggi dapat mencerminkan nilai perusahaan yang tinggi pula (Wijaya \& Sedana, 2015). Nilai perusahaan yang tinggi akan membuat rasa percaya seorang investor akan meningkat, baik itu pada kinerja perusahaan saat ini maupun pada prospek perusahaan di masa depan. 
Nilai perusahaan tidak hanya dapat dilihat dari harga saham suatu perusahaan saja, namun salah satu alat ukur yang dapat digunakan untuk mengetahui suatu nilai perusahaan yaitu price to book value. Menurut (Brigham \& Houston, 2011:152) price book value (PBV) adalah perbandingan antara harga saham dengan nilai buku per lembar saham. Semakin tinggi price to book value maka semakin tinggi pula tingkat kemakmuran dari para pemegang saham, dimana hal ini merupakan tujuan utama dari suatu perusahaan.

Secara normatif tujuan keputusan keuangan adalah untuk memaksimumkan nilai perusahaan atau memaksimumkan kemakmuran pemegang saham (Wiagustini, 2014:9). Nilai perusahaan yang dicerminkan melalui harga saham suatu perusahaan, dimana pergerakan harga saham tentu dipengaruhi oleh beberapa faktor seperti kondisi fundamental emiten, tingkat suku bunga, indeks harga saham dan lain sebagainya. Pada kondisi fundamental perusahaan dapat dilihat dari kondisi internal perusahaan. Faktor fundamental merupakan faktor yang berkaitan dengan kondisi keuangan perusahaan yang tercermin dalam kinerja keuangan perusahaan. Analisis fundamental menggunakan data fundamental yaitu data yang berasal dari laporan keuangan perusahaan, misalnya laba, dividen yang dibayar, penjualan, dan lain sebagainya (Jogiyanto, 2016:188). Menurut (Wiagustini, 2014:75) untuk mengetahui kondisi keuangan perusahaan dapat dilakukan dengan cara menganalisis rasio keuangan, dimana dalam analisis rasio keuangan harus memperhatikan beberapa aspek seperti, aspek likuiditas, solvabilitas (leverage), rentabilitas (profitabilitas), aktivitas usaha, dan aspek penilaian (pasar). 
Penelitian ini membahas dua faktor yang dianggap dapat memengaruhi nilai perusahaan yaitu leverage dan ukuran perusahaan. Alasan memilih kedua faktor yang dianggap memengaruhi nilai perusahaan karena masih terdapat perdebatan mengenai hasil yang diperoleh dari penelitian sebelumnya. Berdasarkan hal tersebut maka penelitian ini menarik dilakukan untuk membuktikan hasil yang sebenarnya.

Suatu perusahaan dapat mengandalkan sumber dana dari dalam perusahaan yaitu berupa penyusutan dan laba ditahan, sedangkan sumber dana dari luar yaitu berupa hutang dan penerbitan saham (Sari \& Abundanti, 2014). Untuk meningkatkan modal guna memperoleh keuntungan yang lebih tinggi, suatu perusahaan dapat menggunakan hutang (leverage) sebagai alat yang dipergunakan untuk meningkatkan modal.

Leverage dapat diartikan sebagai kemampuan suatu perusahaan untuk melunasi kewajiban finansial perusahaan baik dalam jangka pendek maupun jangka panjang atau rasio yang mengukur sejauh mana perusahaan dibiayai dengan hutang (Wiagustini, 2014:76). Jadi leverage yaitu suatu rasio keuangan yang digunakan unutk mengukur pendanaan suatu perusahaan yang berasal dari penggunaan hutang. Namun banyak anggapan bahwa apabila perusahaan terlalu banyak melakukan pendanaan dengan hutang, maka dianggap tidak sehat karena dapat mengakibatkan penurunan laba (Sari \& Abundanti, 2014). Jadi pengelolaan leverage sangatlah penting, karena sesuai dengan trade off theory yang menjelaskan mengenai keseimbangan antara manfaat yang akan diperoleh akibat dari penggunaan hutang, dimana ketika perusahaan dalam kegiatan operasinya 
menggunakan hutang namun manfaat yang diperoleh dari penggunaan hutang jauh lebih besar dari jumlah hutang maka penggunaan hutang diperbolehkan. Sebaliknya, ketika penggunaan hutang tidak memberikan manfaat yang besar maka penambahan hutang tidak diperbolehkan.

Beberapa penelitian yang dilakukan oleh Cheng \& Tzeng (2011), Ramadan (2015), Kouki et al. (2011), Febrianti (2012), serta Obradovich \& Gill (2012) mengungkapkan bahwa leverage berpengaruh positif signifikan terhadap nilai perusahaan, yang artinya semakin tinggi nilai leverage maka semakin tinggi pula nilai perusahaan. Namun hasil penelitian dari Ogolmagai (2013), Hartono et al. (2013), dan Kodongo et al. (2014), mengungkapkan bahwa leverage berpengaruh negatif terhadap nilai perusahaan. Penelitian yang dilakukan oleh Sujoko \& Soebiantoro (2007), serta Dj et al. (2012) memperoleh hasil bahwa leverage berpegaruh signifikan dan negatif terhadap nilai perusahaan, yang artinya kelebihan hutang akan berdampak buruk pada nilai perusahaan. Penelitian yang dilakukan oleh Novari \& Lestari (2016), serta Pratiska (2012) menyatakan bahwa leverage tidak berpengaruh signifikan terhadap nilai perusahaan.

Variabel selain leverage yang dapat digunakan untuk menentukan nilai perusahaan yaitu ukuran perusahaan. Menurut (Riyanto, 2010:343) ukuran perusahaan adalah besar kecilnya perusahaan yang dilihat dari besar nilai ekuitas, nilai penjualan atau nilai total aktiva. Besar (ukuran) perusahaan dapat dinyatakan dalam satuan total aktiva, penjualan, dan kapitalisasi pasar. Semakin besar total aktiva suatu perusahaan, maka semakin besar pula modal yang ditanam. Begitu juga dengan semakin banyak penjualan maka semakin banyak pula perputaran 
uang dalam perusahaan tersebut, serta semakin besar kapitalisasi pasar maka semakin dikenal suatu perusahaan dalam masyarakat. Perusahaan yang memiliki total aktiva yang besar maka menunjukkan bahwa suatu perusahaan tersebut telah mencapai tahap kedewasaannya. Pada tahap kedewasaan tersebut arus kas perusahaan sudah positif dan dianggap memiliki prospek yang baik dalam kurun waktu yang relatif lama.

Total aktiva yang dimiliki perusahaan merupakan cerminan dari besar atau kecilnya ukuran perusahaan dan dapat juga dilihat dari besar kecilnya modal yang dipergunakan (Prastuti \& Sudiartha, 2016). Ukuran perusahaan yang semakin besar menunjukkan bahwa perusahaan tersebut mengalami perkembangan sehingga investor akan merespon positif hal tersebut dan nilai perusahaan juga akan meningkat. Pada umumnya perusahaan yang memiliki size yang cukup besar, maka perusahaan tersebut cenderung lebih mudah untuk mendapat kepercayaan oleh kreditur dalam mendapatkan sumber dana baik dari internal maupun eksternal perusahaan yang mampu digunakan untuk meningkatkan keuntungan perusahaan (Pramana \& Mustanda, 2016).

Beberapa penelitian yang dilakukan oleh Pratiwi et al. (2016), Hidayah (2014), Putu et al. (2014), Moeljadi (2014), Rasyid et al. (2015), serta Pratama \& Wiksuana (2016) memperoleh hasil bahwa ukuran perusahaan berpengaruh signifikan dan positif terhadap nilai perusahaan. Namun hasil yang dilakukan oleh Priyastuty (2014), Dewi \& Wirajaya (2013), serta Gultom \& Wijaya (2013) menyatakan bahwa ukuran perusahaan tidak berpengaruh signifikan terhadap nilai perusahaan. Hasil yang diperoleh dari penelitian Prastuti \& Sudiartha (2016) 
mengungkapkan bahwa ukuran perusahaan berpengaruh negatif dan signifikan terhadap nilai perusahaan. Rumondor et al. (2015) memperoleh hasil bahwa ukuran perusahaan berpengaruh negatif tidak signifikan terhadap nilai perusahaan.

Regulasi selalu menjadi faktor yang pasti berdampak pada bisnis sebuah industri. Hal yang sama terjadi ketika pemerintah Indonesia memberlakukan regulasi terkait jaminan sosial, yakni Badan Penyelenggara Jaminan Sosial (BPJS). Khusus BPJS kesehatan, pengaruh regulasi ini kental dirasakan oleh para pelaku bisnis farmasi. Dengan berlakunya regulasi tersebut, maka produksi obatobatan oleh indutri farmasi akan meningkat karena bertambahnya konsumen yang memiliki kartu Jaminan Kesehatan Nasional (JKN) yang merupakan produk dari BPJS.

Bertambahnya jumlah penduduk tiap tahun di Indonesia akan berdampak pada bertambahnya penjualan dari industri farmasi, hal ini dikarenakan semakin besar penduduk di suatu negara akan semakin besar juga kebutuhan obat-obatan yang dikonsumsi oleh penduduk di negara tersebut. Pasar farmasi Indonesia tumbuh $7,49 \%$ pada tahun 2016, berdasarkan berita yang dikutip dari industri.bisnis.com pada Selasa, 06 Juni 2017 (Dara Aziliya, 2017) dan rata-rata tumbuh 20,6\% per tahun (CAGR) terhitung sejak 2011-2016. Berdasar data realisasi investasi dari Badan Koordinasi Penanaman Modal (BKPM) dalam penanaman modal dalam negeri (PMDN), sektor itu didominasi oleh industri kimia dasar, barang kimia, dan farmasi senilai Rp. 12,9 triliun. Lalu untuk realisasi penanaman modal asing (PMA), industri tersebut masuk dalam lima besar investasi dengan nilai sebesar US\$ 700 juta. Pada tahun ini industri farmasi 
diprediksi mampu mengalami pertumbuhan mencapai $10 \%$ berdasarkan berita yang dikutip dari mediaindonesia.com pada Selasa, 06 Juni 2017 (Arvirianty, 2017). Tingginya nilai investasi industri kimia dasar, barang kimia, dan farmasi menunjukkan investor masih optimis sehingga industri ini akan menjadi salah satu fokus utama pemerintah untuk investasi di Indonesia dalam beberapa tahun ke depan, melihat semakin luasnya jangkauan dari program Jaminan Kesehatan Nasional (JKN) atau BPJS Kesehatan.

Indonesia dapat menjadi pasar farmasi yang paling menjanjikan dibanding negara lain di kawasan Asia Tenggara. Ada beberapa faktor yang menjadi driver pertumbuhan industri farmasi yang ada di Indonesia yaitu jumlah penduduk Indonesia yang besar, kesadaran masyarakat yang semakin tinggi akan kesehatan, tingkat perekonomian masyarakat yang terus meningkat, dan akses kesehatan yang meningkat seiring implementasi BPJS kesehatan.

Tabel 1.

Rata-rata Leverage (DER), Ukuran Perusahaan (Size), dan Nilai Perusahaan (PBV) pada Perusahaan Sektor Farmasi Tahun 2013-2016

\begin{tabular}{lcccc}
\hline & \multicolumn{4}{c}{ Tahun } \\
\cline { 2 - 5 } Variabel & 2013 & 2014 & 2015 & 2016 \\
\hline Leverage (\%) & 0,51 & 0,28 & 0,56 & 0,55 \\
Ukuran perusahaan (Jutaan Rupiah) & 14,37 & 14,41 & 14,45 & 14,55 \\
Nilai perusahaan (\%) & 3,66 & 4,06 & 2,83 & 6,74 \\
\hline
\end{tabular}

Sumber: Data diolah, 2017

Berdasarkan Tabel 1. di atas dapat dilihat bahwa rata-rata nilai perusahaan pada sektor farmasi di Bursa Efek Indonesia dari tahun 2013 hingga tahun 2016 menunjukkan perubahan setiap tahun yang bervariasi dan menunjukkan fluktuasi naik turun di tiap tahun yang berbeda. Dengan adanya fluktuasi tersebut, investor akan kesulitan untuk memprediksi nilai perusahaan dimasa yang akan datang, 
sehingga keputusan investor untuk berinvestasi masih diragukan. Oleh karena itu sangat penting bagi eksekutif perusahaan untuk dapat membuat keputusan mengenai leverage dan ukuran perusahaan secara tepat dengan mempertimbangkan fungsi manajemen keuangan, dimana satu keputusan keuangan yang diambil akan memengaruhi keputusan keuangan yang lainnya dan berdampak pada nilai perusahaan.

Berdasarkan pemaparan latar belakang dan adanya research gap dari beberapa penelitian-penelitian sebelumnya mengenai leverage dan ukuran perusahaan terhadap nilai perusahaan, maka penelitian ini dirasa penting untuk dilakukan pada Perusahaan Sektor Farmasi yang terdaftar di BEI periode 20132016.

Berdasarkan uraian di atas, dapat disimpulkan rumusan masalah sebagai berikut: 1) Bagimanakah pengaruh leverage pada nilai perusahaan sektor farmasi yang terdaftar di BEI periode 2013-2016?; 2) Bagaimanakah pengaruh ukuran perusahaan pada nilai perusahaan sektor farmasi yang terdaftar di BEI periode 2013-2016?

Berdasarkan rumusan masalah di atas, maka tujuan penelitian ini adalah untuk mengetahui: 1) Pengaruh leverage pada nilai perusahaan sektor farmasi yang terdaftar di BEI periode 2013-2016.; 2) Pengaruh ukuran perusahaan pada nilai perusahaan sektor farmasi yang terdaftar di BEI periode 2013-2016.

Adapun kegunaan yang dapat diperoleh dari penelitian ini adalah sebagai berikut: 1) Kegunaan Teoritis, Penelitian ini diharapkan dapat memberikan kontribusi pada pengembangan ilmu ekonomi akuntansi pasar modal dan sebagai 
bahan studi atau literatur tambahan terhadap penelitian yang sudah ada sebelumnya.; 2) Kegunaan Praktis, penelitian ini diharapkan dapat memberikan masukan dan informasi sebagai bahan pertimbangan bagi perusahaan untuk menentukan keputusan serta kebijakan mengenai kinerja perusahaan pada masa yang akan datang.Bagi perusahaan yang berbentuk Perseroan Terbatas (PT) telebih untuk perusahaan yang telah terdaftar di pasar modal, seringkali terjadi pemisahan antara pengelola perusahaan dengan pemilik perusahaan. Disamping itu, untuk perusahaan yang berbentuk perseroan terbatas, tanggung jawab pemilik hanya terbatas pada modal yang disetorkan. Artinya, apabila perusahaan mengalami kebangkrutan, maka modal sendiri (ekuitas) yang telah disetorkan oleh para pemilik perusahaan mungkin sekali akan hilang, tetapi kekayaan pribadi pemilik tidak akan diikutsertakan untuk menutup kerugian tersebut (Husnan, 2003).

Jensen \& Meckling (1976) menjelaskan hubungan keagenan di dalam teori agensi (agency theory) bahwa perusahaan merupakan kumpulan kontrak (nexus of contract) antara pemilik sumber daya ekonomis (principal) dan manager (agent) yang mengurus penggunaan dan pengendalian sumber daya tersebut. Agency theory memiliki asumsi bahwa masing-masing individu semata-mata termotivasi oleh kepentingan diri sendiri sehingga menimbulkan konflik kepentingan antara principal dan agent. Pemegang saham sebagai pihak principal mengadakan kontrak untuk memaksimalkan kesejahteraan dirinya dengan profitabilitas yang selalu meningkat. Manager sebagai agent termotivasi untuk memaksimalkan 
pemenuhan kebutuhan ekonomi dan psikologisnya antara lain dalam hal memperoleh investasi, pinjaman, maupun kontrak kompensasi (Sugiyono, 2014).

Masalah keagenan muncul karena adanya perilaku oportunitik dari agent, yaitu perilaku manajemen untuk memaksimalkan kesejahteraannya sendiri yang berlawanan dengan kepentingan principal. Manajer memiliki dorongan untuk memilih dan menerapkan metode akuntansi yang dapat memperlihatkan kinerjanya yang baik untuk tujuan mendapatkan bonus dari principal.

Sebuah perusahaan dikatakan tidak solvabel apabila total hutang perusahaan lebih besar daripada total aset yang dimiliki perusahaan. Jumlah hutang yang semakin besar akan menunjukkan risiko investasi yang semakin besar pula apabila perusahaan tidak dapat melunasi kewajibannya tepat pada waktunya. Solvabilitas (leverage) mencerminkah sejauh mana aset perusahaan dibiayai oleh hutang dibandingkan dengan modal sendiri. Dengan semakin tingginya rasio leverage menunjukkan semakin besarnya dana yang disediakan oleh kreditur. Hal tersebut akan membuat investor berhati-hati untuk berinvestasi di perusahaan yang rasio leverage nya tinggi karena semakin tinggi rasio leverage nya semakin tinggi pula resiko investasinya (Weston \& Copeland, 1992). Teori struktur modal model trade off menyatakan bahwa hutang yang semakin meningkat akan menimbulkan financial distress. Terjadinya financial distress akan mengakibatkan nilai perusahaan akan mengalami penurunan.

Penelitian sebelumnya yang mendukung untuk membangun hipotesis pertama dari penelitian ini yaitu Ogolmagai (2013), Hartono et al. (2013), Kodongo et al. (2014), Sujoko \& Soebiantoro (2007), serta Dj et al. (2012), 
memperoleh hasil leverage berpengaruh signifikan dan memiliki arah yang negatif pada nilai perusahaan. Adapun hipotesis yang dapat dibangun berdasarkan uraian tersebut yaitu:

$\mathrm{H}_{1}$ : Leverage berpengaruh negatif signifikan pada nilai perusahaan.

Perusahaan besar ataupun kecil dapat memperlihatkan melalui seberapa banyak perusahaan memiliki total aktiva. Perusahaan yang memiliki ukuran semakin besar akan membuat seorang investor menaruh perhatian yang besar pada perusahaan tersebut. Kondisi tersebut dapat terjadi karena perusahaan besar cenderung mempunyai kondisi yang semakin baik. Kondisi perusahaan yang baik dapat membuat investor ingin memiliki saham perusahaan sehingga dapat meningkatkan penawaran harga saham di pasaran. Calon investor akan berharap memperoleh dividen yang semakin tinggi dari perusahaan yang memiliki ukuran besar. Peningkatan penawaran saham di pasar modal akan sejalan dengan peningkatan pada nilai perusahaan.

Penelitian sebelumnya yang mendukung untuk membangun hipotesis kedua dalam penelitian ini yaitu Pratiwi et al. (2016), Hidayah (2014), Putu et al. (2014), Rasyid et al. (2015), serta Pratama \& Wiksuana (2016) memperoleh hasil ukuran perusahaan berpengaruh signifikan dan memiliki arah yang positif pada nilai perusahaan. Adapun hipotesis kedua yang dapat dibangun berdasarkan uraian tersebut yaitu:

$\mathrm{H}_{2}$ : Ukuran perusahaan berpengaruh positif signifikan pada nilai perusahaan. 


\section{METODE PENELITIAN}

Penelitian ini dilakukan dengan pendekatan kuantitatif. Pendekatan kuantitatif adalah pendekatan yang menggunakan data dalam bentuk angka pada analisis statistik. Penelitian ini bertujuan untuk mencari pengaruh variabel tertentu terhadap variabel lainnya. Berdasarkan tingkat penjelasan dari kedudukan variabelnya maka penelitian ini bersifat asosiatif kausal, yaitu penelitian yang mencari hubungan (pengaruh) sebab akibat, yaitu variabel independen/variabel yang memengaruhi $(\mathrm{X})$ terhadap variabel dependen/variabel yang dipengaruhi (Y) (Sugiyono, 2014:56). Dalam penelitian ini variabel dependen adalah nilai perusahaan, sedangkan variabel independen adalah leverage, dan ukuran perusahaan.

Variabel Bebas

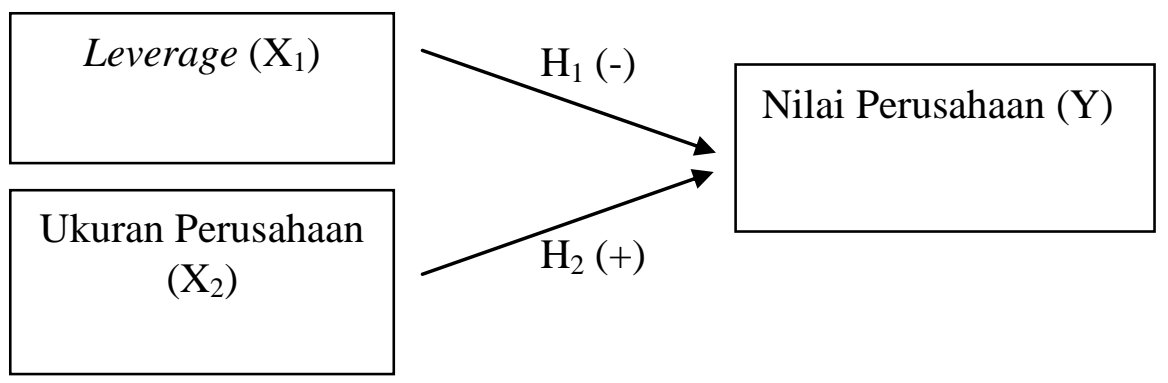

Gambar 1. Kerangka Pemikiran

Sumber: Data diolah, 2017

Penelitian ini dilakukan pada perusahaan sektor farmasi yang terdaftar di Bursa Efek Indonesia (BEI) dengan cara mengakses situs resmi Bursa Efek Indonesia (BEI) di www.idx.co.id. Objek penelitian ini adalah nilai perusahaan kelompok industri sektor farmasi yang terdaftar di Bursa Efek Indonesia periode 2013-2016. 
Variabel yang akan diteliti dalam penelitian ini diindentifikasi menjadi dua variabel bebas dan variabel terikat. Menurut (Sugiyono, 2014:59), variabel bebas adalah merupakan variabel yang memengaruhi atau yang menjadi sebab perubahannya atau timbulnya variabel dependen (terikat). Variabel bebas dalam penelitian ini adalah leverage $\left(\mathrm{X}_{1}\right)$, dan ukuran perusahaan $\left(\mathrm{X}_{2}\right)$. Variabel terikat merupakan variabel yang dipengaruhi atau yang menjadi akibat karena adanya variabel bebas (Sugiyono, 2014:59). Variabel terikat dalam penelitian ini adalah nilai perusahaan $(\mathrm{Y})$.

Leverage merupakan pengukur besarnya aktiva yang dibiayai dengan hutang-hutang yang digunakan untuk membiayai aktiva berasal dari kreditur, bukan dari pemegang saham ataupun dari investor. Leverage atau solvabilitas suatu perusahaan menunjukkan kemampuan perusahaan untuk memenuhi segala kewajiban finansialnya apabila perusahaan tersebut likuidasi pada suatu waktu. Leverage diukur dalam periode empat tahun dari 2013-2016 pada Perusahaan Sektor Farmasi yang terdaftar di Bursa Efek Indonesia (BEI). Tingkat penggunaan hutang dari suatu perusahaan dapat ditunjukkan dengan menggunakan rasio hutang terhadap ekuitas (DER). (Wiagustini, 2014:88) merumuskan rasio leverage sebagai berikut:

$$
\text { LEVERAGE }=\frac{\text { Total hutang }}{\text { Total ekuitas }}
$$

Ukuran perusahaan dalam penelitian ini dinyatakan dengan total aktiva, semakin besar total aktiva perusahaan maka akan semakin besar pula ukuran perusahaan itu. Semakin besar aktiva maka semakin banyak modal ditanam. Ukuran perusahaan dapat dilihat dari total aset yang dimiliki oleh perusahaan 
(Suharli, 2006). Dalam penelitian ini ukuran perusahaan dinilai dengan logaritma natural dari total aset Perusahaan Sektor Farmasi yang terdaftar di Bursa Efek Indonesia (BEI) periode 2013-2016 dengan menggunakan rumus sebagai berikut:

SIZE $=\log$ of total assets

Variabel dependen yang digunakan dalam penelitian ini adalah nilai perusahaan (Y). Nilai perusahaan merupakan nilai atau harga pasar yang berlaku atas saham umum suatu perusahaan. Nilai perusahaan dapat diukur dengan PBV (Price to Book Value). PBV akan membandingkan harga per lembar saham dengan nilai buku per lembar saham yang diukur dalam periode penelitian empat tahun dari 2013-2016 pada Perusahaan Sektor Farmasi yang terdaftar di Bursa Efek Indonesia (BEI). Rasio PBV dapat dihitung dengan rumus sebagai berikut (Wiagustini, 2014:81):

$$
\text { PBV }=\frac{\text { Harga per lembar saham }}{\text { Nilai buku per lembar saham }}
$$

Sumber data yang digunakan dalam penelitian ini adalah data sekunder. Data sekunder adalah data dalam bentuk sudah ada, sudah dikumpulkan, dan diolah oleh pihak lain (Sugiyono, 2014:141). Penelitian ini menggunakan data sekunder meliputi annual report perusahaan farmasi yang terdaftar di Bursa Efek Indonesia dengan mengunduh melalui situs resmi BEI yaitu www.idx.co.id.

Populasi adalah wilayah generalisasi yang terdiri atas obyek/subyek yang mempunyai kualitas dan karakteristik tertentu yang diterapkan oleh peneliti untuk dipelajari dan kemudian ditarik kesimpulannya (Sugiyono, 2014:115). Populasi dalam penelitian ini meliputi seluruh perusahaan industri farmasi yang terdaftar di Bursa Efek Indonesia tahun 2013-2016. 
Sampel merupakan bagian dari jumlah dan karakteristik yang dimiliki oleh populasi (Sugiyono, 2014:116). Metode penentuan sampel yang digunakan dalam penelitian ini adalah nonprobability sampling (teknik pengambilan sampel yang tidak memberi peluang atau kesempatan sama bagi setiap unsur atau anggota populasi untuk dipilih menjadi sampel) dengan menggunakan teknik sampling purposive yaitu teknik penentuan sampel dengan pertimbangan tertentu (Sugiyono, 2014:120). Adapun kriteria sampel yang dipilih adalah sebagai berikut:

Tabel 2.

Pemilihan Sampel Penelitian

\begin{tabular}{clc}
\hline No. & \multicolumn{1}{c}{ Kriteria } & Jumlah \\
\hline 1 & Perusahaan farmasi yang terdaftar di BEI tahun 2013-2016 & 10 \\
2 & $\begin{array}{l}\text { Perusahaan tidak melaporkan laporan keuangan dan laporan tahunan secara } \\
\text { berturut-turut selama tahun 2013-2016 } \\
\text { Jumlah perusahaan yang terpilih sebagai sampel }\end{array}$ & $(2)$ \\
\hline Sumber:
\end{tabular}

Metode pengumpulan data dalam penelitian ini adalah dengan menggunakan teknik observasi non partisipan, yaitu peneliti tidak ikut secara langsung dalam kegiatan sehari-hari objek yang diamati dan digunakan sebagai sumber data penelitian (Sugiyono, 2014:204). Dimana pengumpulan data dilakukan dengan mencatat data-data dan informasi yang terkait dengan penelitian.

Teknik analisis data yang digunakan dalam penelitian ini adalah analisis regresi linier berganda. Analisis regresi linier berganda digunakan untuk mengetahui ada tidaknya pengaruh variabel bebas pada variabel terikat. Dalam penelitian ini, teknik analisis data digunakan untuk mengetahui pengaruh leverage, dan ukuran perusahaan terhadap nilai perusahaan. Program SPSS 
(Statistical Product and Service Solutions) merupakan software yang digunakan untuk melakukan analisis regresi linier berganda pada penelitian ini.

Model regresi linier berganda ditunjukkan oleh persamaan sebagai berikut:

$$
\mathrm{Y}=\alpha+\beta_{1} \mathrm{X}_{1}+\beta_{2} \mathrm{X}_{2}+\mathrm{e}
$$

Keterangan :

Y : Nilai Perusahaan

$\alpha \quad$ : Nilai konstanta

$\beta_{1} \beta_{2} \quad$ : Koefisien regresi

$\mathrm{X}_{1} \quad$ : Leverage

$\mathrm{X}_{2} \quad$ : Ukuran Perusahaan

e : error

\section{HASIL DAN PEMBAHASAN}

Hasil dari pengujian statistik deskriptif dari variabel nilai perusahaan (PBV), leverage (DER), dan ukuran perusahaan (Size) dari tahun 2013-2016 disajikan pada tabel dibawah ini.

Tabel 3.

Hasil Statistik Deskriptif

\begin{tabular}{lrrrrr}
\hline & N & \multicolumn{1}{c}{ Maximum } & \multicolumn{1}{c}{ Minimum } & Mean & \multicolumn{1}{c}{ Std. Deviation } \\
\hline PBV & 32 & 6.89 & .59 & 3.3778 & 1.73065 \\
Size & 32 & 16.64 & 11.98 & 13.813 & 1.15636 \\
DER & 32 & 1.59 & .07 & .5266 & .31765 \\
\hline Sumber: & & & &
\end{tabular}

Berdasarkan Tabel 3, nilai tertinggi dari nilai perusahaan Sektor Farmasi yang menjadi sampel penelitian adalah 6,89 satuan yang dicapai oleh Kalbe Farma Tbk. pada tahun 2013 dan nilai terendah dicapai oleh Pyridam Farma Tbk. sebesar 0,59 satuan pada tahun 2015. Nilai rata-rata (Mean) pada variabel nilai perusahaan Sektor Farmasi yang terdaftar di Bursa Efek Indonesia periode 20132016 adalah sebesar 3,3778 satuan dan standar deviasinya sebesar 1,73065 satuan. 
Berdasarkan Tabel 3, nilai tertinggi dari variabel leverage perusahaan Sektor Farmasi yang menjadi sampel dalam penelitian adalah sebesar 1,59 satuan yang dicapai oleh Indofarma (Persero) Tbk. pada tahun 2015 dan nilai terendah dicapai oleh Industri Jamu dan Farmasi Sido Muncul Tbk. sebesar 0,07 satuan pada tahun 2014. Nilai DER yang tinggi maupun rendah tersebut dapat dipengaruhi oleh keputusan suatu perusahaan dalam memperoleh sumber pendanaan yang berasal dari penggunaan hutang untuk membiayai kegiatan investasinya. Nilai rata-rata (Mean) pada variabel leverage perusahaan Sektor Farmasi yang terdaftar di Bursa Efek Indonesia periode 2013-2016 adalah sebesar 0,5266 satuan dan standar deviasinya sebesar 0,31765 satuan.

Berdasarkan Tabel 3, nilai tertinggi dari variabel ukuran perusahaan Sektor Farmasi yang menjadi sampel dalam penelitian adalah sebesar 16.64 satuan yang dicapai oleh Kalbe Farma Tbk. pada tahun 2013 dan nilai terendah dicapai oleh Pyridam Farma Tbk. sebesar 11.98 satuan pada tahun 2015. Nilai size yang tinggi maupun rendah tersebut dapat dipengaruhi oleh total aktiva yang dimiliki oleh suatu perusahan, sehingga semakin tinggi total aktiva yang dimiliki maka semakin tinggi pula nilai size dari perusahaan tersebut. Nilai rata-rata (Mean) pada variabel ukuran perusahaan Sektor Farmasi yang terdaftar di Bursa Efek Indonesia periode 2013-2016 adalah sebesar 14,3813 satuan dan standar deviasinya sebesar 1,15636 satuan.

Uji normalitas bertujuan untuk menguji apakah residual dari model regresi yang dibuat berdistribusi normal atau tidak. Pengujian normalitas data dilakukan dengan menggunakan uji Kolmogorof-Smirnov. Jika pada hasil uji Kolmogorof- 
Smirnov menunjukkan nilai signifikansi lebih besar dari 0,05, maka data berdistribusi normal. Sebaliknya, jika nilai signifikansi lebih kecil dari 0,05, maka data tidak berdistribusi normal.

Pengujian dilakukan antara variabel leverage dan ukuran perusahaan dengan residualnya (unstandardized residual) sebagai daftar target variable test yang diuji secara bersamaan (Ghozali, 2009:114). Hasil pengujian memperlihatkan besarnya nilai Kolmogorov-Smirnov $Z$ adalah 1,029 dan nilai Asymp. Sig. (2tailed) lebih besar dari tingkat signifikansi yang telah ditetapkan sebelumnya yaitu 0,05. Oleh karena itu, maka model yang dibuat telah berdistribusi normal dan dapat digunakan untuk analisis lebih lanjut.

Uji multikolonieritas bertujuan untuk menguji apakah dalam model regresi terdapat korelasi antar variabel bebas. Multikolonieritas dapat dilihat dari nilai tolerance atau variance of inflation factor (VIF). Jika nilai tolerance lebih besar dari 0,1 atau VIF kurang dari 10, maka dapat dikatakan bahwa model regresi telah bebas dari masalah multikolonieritas.

Berdasarkan hasil uji dapat dilihat bahwa nilai tolerance pada masingmasing variabel bebas lebih besar dari nilai tolerance yang telah ditetapkan sebelumnya yaitu 0,1 dan nilai VIF pada masing-masing variabel bebas lebih kecil dari nilai VIF yang telah ditetapkan sebelumnya yaitu 10. Berdasarkan hasil tersebut menunjukkan bahwa tidak terdapat gejala multikolonieritas dari model regresi yang dibuat, sehingga model tersebut layak digunakan untuk memprediksi.

Uji heteroskedastisitas bertujuan untuk menguji apakah dalam model regresi terjadi ketidaksamaan varians dari residual satu pengamatan ke 
pengamatan lainnya. Pengujian ini menggunakan uji Glejser dimana jika signifikansi dari hasil regresi nilai absolut residual terhadap variabel bebas lebih besar dari 0,05, maka model regresi tidak mengandung adanya gejala heteroskedastisitas.

Berdasarkan hasil uji menunjukkan bahwa nilai Sig. dari variabel leverage (DER) sebesar 0,078 dan ukuran perusahaan (Size) sebesar 0,749 yang mana nilai dari setiap variabel tersebut lebih besar dari tingkat signifikansi yang telah ditetapkan sebelumnya yaitu 0,05 . Berdasarkan hasil tersebut menunjukkan bahwa tidak terdapat pengaruh antara variabel bebas terhadap absolut residual, dengan demikian model yang dibuat tidak mengandung gejala heteroskedastisitas.

Uji autokorelasi dilakukan dengan tujuan untuk menguji apakah dalam suatu model regresi linier ada korelasi antara kesalahan pengganggu pada tahun $\mathrm{t}$ dengan kesalahan pada tahun t-1. Uji autokorelasi dapat dilakukan dengan uji Durbin-Watson (DW-test) atau d statistic terhadap variabel pengganggu (disturbance error term).

Berdasarkan hasil uji dapat dilihat bahwa nilai Durbin-Watson adalah sebesar 2,257 dengan jumlah sampel 32 dan jumlah variabel bebas yaitu 2. Nilai $d_{u}=1,5736$ dan $d_{L}=1,3093$ sehingga $2-d_{u}=2-1,5736=0,4264$. Hal ini berarti nilai Durbin-Watson berada di antara nilai $d_{u}$ dan $\left(4-d_{u}\right)$ yaitu $(1,5736<2,257<$ $2,4264)$ yang menunjukkan bahwa tidak ada gejala autokorelasi sehingga dapat dilakukan analisis berikutnya.

Analisis regresi linier berganda bertujuan untuk mengetahui pengaruh antara variabel bebas terhadap variabel terikat atas perubahan dari setiap peningkatan 
maupun penurunan variabel bebas yang akan memengaruhi variabel terikat. Pengujian regresi linier berganda digunakan untuk mengetahui pengaruh leverage dan ukuran perusahaan terhadap nilai perusahaan Sektor Farmasi yang terdaftar di Bursa Efek Indonesia tahun 2013-2016. Hasil olahan data dengan SPSS menggunakan model analisis regresi linear berganda dapat dilihat pada Tabel 4 .

Tabel 4.

Hasil Analisis Regresi Linier Berganda

\begin{tabular}{|c|c|c|c|c|c|c|}
\hline \multirow{2}{*}{\multicolumn{2}{|c|}{ Model }} & \multicolumn{2}{|c|}{ Unstandardized } & \multicolumn{3}{|l|}{ Standardized } \\
\hline & & B & Std. Error & Beta & $\mathrm{t}$ & Sig. \\
\hline 1 & (Constant) & -7.484 & 3.031 & & -2.469 & .020 \\
\hline & Leverage & -1.864 & .723 & -.342 & -2.578 & .015 \\
\hline & Size & .824 & .199 & .550 & 4.146 & .000 \\
\hline & justed $R^{2}$ & & & & & .535 \\
\hline $\mathrm{F}$ & & & & & & 18.811 \\
\hline & F & & & & & .000 \\
\hline
\end{tabular}

Sumber: Data diolah, 2017

Dari hasil analisis regresi linear berganda pada Tabel 4, dapat dibuat persamaan sebagai berikut:

$$
\mathrm{Y}=-7,484-1,864 \mathrm{X}_{1}+0,824 \mathrm{X}_{2}+\mathrm{e}
$$

Berdasarkan persamaan regresi diatas dapat dijelaskan sebagai berikut: Nilai konstanta $(\alpha)$ sebesar -7,484 berarti apabila perusahaan tidak melakukan pinjaman dan ukuran perusahaan nilainya adalah 0 , maka nilai perusahaan akan menurun sebesar 7,484 satuan. Nilai koefisien regresi leverage $\left(\beta_{1}\right)$ sebesar $(-1,864)$ berarti apabila leverage meningkat sebesar 1 satuan dengan anggapan variabel lainnya konstan, maka nilai perusahaan akan menurun sebesar 1,864 satuan. Nilai koefisien regresi ukuran perusahaan $\left(\beta_{2}\right)$ sebesar 0,824 berarti apabila ukuran perusahaan meningkat sebesar 1 satuan dengan anggapan variabel lainnya konstan maka nilai perusahaan akan meningkat sebesar 0,824 satuan. 
Uji F dilakukan untuk menguji kelayakan atau validitas model regresi linear berganda dan digunakan untuk mengetahui ada tidaknya pengaruh secara bersama-sama (simultan) variabel bebas terhadap variabel terikat. Apabila hasil uji $\mathrm{F}$ menyatakan nilai signifikansi $(\alpha)$ lebih kecil dari 0,05 , maka variabel bebas secara bersama-sama mempunyai pengaruh terhadap variabel terikat. Hasil uji pada Tabel 4 menunjukkan bahwa nilai signifikansi $\mathrm{F}$ sebesar 0,000 lebih kecil dari 0,05. Dengan demikian variabel leverage dan ukuran perusahaan secara bersama-sama (simultan) berpengaruh terhadap variabel nilai perusahaan.

Koefisien determinasi $\left(\mathrm{R}^{2}\right)$ bertujuan untuk mengukur seberapa jauh kemampuan model dalam menerangkan variasi variabel terikat. Nilai koefisien determinasi adalah antara nol dan satu. Semakin kecil nilai $\mathrm{R}^{2}$ menunjukkan semakin terbatas kemampuan variabel-variabel bebas dalam menjelaskan variabel terikat. Nilai yang mendekati satu berarti variabel bebas memberikan hampir semua informasi yang dibutuhkan untuk memprediksi variasi variabel terikat. Hasil uji pada Tabel 4 menunjukkan nilai Adjusted R Square sebesar 0,535 berarti bahwa variasi variabel independen mampu menjelaskan 53,5\% variasi variabel dependen, sedangkan sisanya yaitu sebesar $46,5 \%$ dijelaskan oleh variabel lain diluar variabel independen.

Uji t dilakukan untuk mengetahui pengaruh masing-masing variabel bebas secara individu terhadap variabel terikat. Pengujian dilakukan dengan melihat nilai signifikansi t masing-masing variabel pada output hasil regresi menggunakan SPSS dengan level signifikansi 0,05 ( $\alpha=5 \%)$. Jika nilai signifikansi lebih kecil 
dari $\alpha$, maka hipotesis diterima, yang berarti variabel bebas berpengaruh signifikan terhadap variabel terikat.

Berdasarkan Tabel 4 diperoleh nilai signifikansi uji t untuk variabel leverage sebesar 0,015 lebih kecil dari 0,05 . Nilai $\beta_{1}=(-2.578)$ menunjukkan variabel leverage berpengaruh negatif pada nilai perusahaan. Hal ini menunjukkan $\mathrm{H}_{0}$ ditolak dan $\mathrm{H}_{1}$ diterima.

Berdasarkan Tabel 4 diperoleh nilai signifikansi uji t untuk variabel ukuran perusahaan sebesar 0,000 lebih kecil dari 0,05 . Nilai $\beta_{2}=4,146$ menunjukkan variabel ukuran perusahaan berpengaruh positif pada nilai perusahaan. Hal ini menunjukkan $\mathrm{H}_{0}$ ditolak dan $\mathrm{H}_{2}$ diterima.

Pengujian dari hipotesis pertama dalam penelitian ini menghasilkan bahwa leverage berpengaruh negatif signifikan terhadap nilai perusahaan. Hal ini memperlihatkan dari nilai koefisien regresi antara leverage terhadap nilai perusahaan yaitu sebesar $(-1,864)$ serta nilai signifikansi dari variabel leverage lebih kecil dari tingkat signifikansi yang digunakan $(\alpha=0,05)$ yaitu Sig. $=0,015<$ 0,05 yang artinya variabel leverage berpengaruh negatif dan signifikan terhadap variabel nilai perusahaan. Hasil ini sesuai dengan hasil penelitian sebelumnya yang dilakukan oleh Ogolmagai (2013), Hartono et al. (2013), Kodongo et al. (2014), Sujoko \& Soebiantoro (2007), serta Dj et al. (2012) yang menemukan bahwa leverage berpengaruh negatif dan signifikan terhadap nilai perusahaan, yang berarti semakin tinggi leverage maka semakin rendah nilai perusahaannya. Hasil dari penelitian ini konsisten dengan teori yang dinyatakan oleh Weston \& Copeland (1992) yang menyatakan bahwa rasio leverage yang tinggi 
menyebabkan turunnya nilai perusahaan karena penggunaan hutang akan memunculkan beban perusahaan berupa biaya bunga yang menyebabkan semakin meningkatnya risiko investasi apabila perusahaan tidak dapat melunasi kewajibannya tepat waktu dan semakin tidak pastinya tingkat pengembalian bagi para pemegang saham biasa (Analisa, 2011). Serta jumlah hutang yang semakin meningkat akan menimbulkan financial distress. Terjadinya financial distress akan mengakibatkan nilai perusahaan akan mengalami penurunan (Sujoko \& Soebiantoro, 2007).

Pengujian dari hipotesis kedua dalam penelitian ini menghasilkan bahwa ukuran perusahaan berpengaruh positif signifikan terhadap nilai perusahaan. Hal ini memperlihatkan dari nilai koefisien regresi antara ukuran perusahaan terhadap nilai perusahaan yaitu sebesar 0,824 serta nilai signifikansi dari variabel ukuran perusahaan lebih kecil dari tingkat signifikansi yang digunakan $(\alpha=0,05)$ yaitu Sig. $=0,000<0,05$ yang artinya variabel ukuran perusahaan berpengaruh positif dan signifikan terhadap variabel nilai perusahaan. Hasil ini sesuai dengan hasil penelitian sebelumnya yang dilakukan oleh Pratiwi et al. (2016), Hidayah (2014), Putu et al. (2014), Rasyid et al. (2015), serta Pratama \& Wiksuana (2016) yang menemukan bahwa ukuran perusahaan berpengaruh positif dan signifikan terhadap nilai perusahaan, yang berarti semakin besar ukuran perusahaan maka semakin tinggi pula nilai perusahaannya.

Ukuran perusahaan merupakan cerminan total aktiva yang dimiliki oleh perusahaan. Dengan semakin besarnya ukuran perusahaan, maka terdapat kecenderungan bahwa semakin banyak investor yang menaruh perhatian pada 
perusahaan tersebut. Hal ini disebabkan karena perusahaan yang besar cenderung memiliki kondisi yang lebih stabil. Kondisi tersebut yang akan menarik perhatian investor untuk memiliki saham perusahaan tersebut karena investor menginginkan perolehan deviden yang besar dari perusahaan tersebut. Peningkatan permintaan saham akan memacu pada peningkatan harga saham di pasar modal. Peningkatan tersebut menunjukkan bahwa perusahaan memiliki nilai yang lebih besar (Analisa, 2011).

\section{SIMPULAN}

Berdasarkan pada hasil analisis data dan pembahasan yang telah dipaparkan pada bab sebelumnya, maka dapat disimpulkan bahwa Leverage secara signifikan berpengaruh negatif terhadap nilai perusahaan. Ukuran perusahaan secara signifikan berpengaruh positif terhadap nilai perusahaan.

Berdasarkan hasil penelitian disarankan agar perusahaan sektor farmasi yang terdaftar di Bursa Efek Indonesia memperhatikan beberapa faktor yang dapat memengaruhi nilai perusahaan. Faktor yang dimaksud adalah leverage dan ukuran perusahaan karena kedua faktor tersebut telah terbukti dapat memengaruhi nilai perusahaan dalam artian kedua faktor tersebut mampu memengaruhi nilai perusahaan. Leverage penting untuk diperhatikan karena perusahaan harus berhati-hati dalam menambah hutang sehingga terdapat keseimbangan antara manfaat dan pengorbanan dalam kaitannya dengan hutang. Bagi pemegang saham perusahaan sektor farmasi yang terdaftar di Bursa Efek Indonesia hendaknya dapat memberikan batasan kepada manajemen dalam penggunaan hutang, karena 
penggunaan hutang yang lebih rendah akan dapat mengurangi biaya agensi yang harus dikeluarkan akibat perbedaan kepentingan antara manajemen dengan principal, sehingga laba perusahaan dapat dimaksimalkan serta meningkatkan nilai perusahaan. Keterbatasan dalam penelitian ini hendaknya dapat disempurnakan pada penelitian selanjutnya yang akan mengangkat permasalahan yang sama, disarankan untuk mempertimbangkan penggunaan variabel-variabel lain yang dianggap mampu memengaruhi nilai perusahaan. Menambah jumlah sampel yang tidak hanya terfokus pada Perusahaan Sektor Farmasi serta memperpanjang periode penelitian merupakan saran untuk mendapatkan hasil penelitian yang lebih akurat.

\section{REFRENSI}

Analisa, Y. (2011). Pengaruh Ukuran Perusahaan, Leverage, Profitabilitas dan Kebijakan Dividen Terhadap Nilai Perusahaan. Universitas Diponogoro.

Arvirianty, A. (2017). Industri Farmasi semakin Sehat. Www.Mediaindonesia.Com. Retrieved from http://mediaindonesia.com/read/detail/96887-industri-farmasi-semakin-sehat

Brigham, E. F., \& Houston, J. F. (2011). Essentials of Financial Management. (A. A. Y, Ed.) (11th ed.). Jakarta: Salemba Empat.

Cheng, M., \& Tzeng, Z. (2011). The Effect of Leverage on Firm Value and How The Firm Financial Quality Influence on This Effect. World Journal of Management, 3(2), 30-53.

Dara Aziliya. (2017). JKN Kerek Pertumbuhan Industri Farmasi. Www.Ekonomi.Bisnis.Com. Retrieved from https://ekonomi.bisnis.com/read/20170322/257/639465/jkn-kerekpertumbuhan-industri-farmasi\#

Dewi, A. S. M., \& Wirajaya, A. (2013). Pengaruh Struktur Modal, Profitabilitas, dan Ukuran Perusahaan Pada Nilai Perusahaan. E-Jurnal Akuntansi Universitas Udayana, 4(2), 358-372. 
Dj, A. M., Artini, L. G. S., \& Suarjaya, A. . G. (2012). Pengaruh Kinerja Keuangan Terhadap Nilai Perusahaan pada Perusahaan Manufaktur di Bursa Efek Indonesia. Jurnal Manajemen, Strategi Bisnis, Dan Kewirausahaan, 6(2), 130-138.

Febrianti, M. (2012). Faktor-faktor Yang Memengaruhi Nilai Perusahaan pada Industri Pertambangan di Bursa Efek Indonesia. Jurnal Bisnis Dan Akuntansi, 14(2), 141-156.

Ghozali, I. (2009). Aplikasi Analisis Multivariate Dengan Program SPSS. Semarang: Badan Penerbit Universitas Diponegoro.

Gultom, R., \& Wijaya, S. W. (2013). Analisis Faktor-faktor Yang Memengaruhi Nilai Perusahaan Pada Perusahaan Farmasi di Bursa Efek Indonesia. Jurnal Wira Ekonomi Mikroskil, 3(1), 51-60.

Hartono, U., Subroto, B., Djumahir, \& Irianto, G. (2013). Firm Characteristics, Corporate Governance and Firm Value. International Journal of Business and Behavioral Sciences, 3(8), 9-18.

Hidayah, N. (2014). The Effect of Company Characteristic Toward Firm Value In The Property And Real Estate Company In Indonesia Stock Exchange. International Journal of Business, Economics and Law, 5(1), 1-8.

Husnan, S. (2003). Dasar-Dasar Teori Portofolio dan Analisis Sekuritas (3rd ed.). Yogyakarta: UPP AMP YKPN.

Jensen, M. C., \& Meckling, W. H. (1976). Theory of the Firm: Managerial Behavior, Agency Costs and Ownership Structure Theory of the Firm: Managerial Behavior, Agency Costs and Ownership Structure. Journal of Financial Economics, 3(4), 305-360. https://doi.org/10.1016/0304405X(76)90026-X

Jogiyanto, H. (2016). Teori Portofolio dan Analisis Investasi (10th ed.). Yogyakarta: BPFE.

Kodongo, O., Mokoaleli-Mokoteli, T., \& Maina, L. N. (2014). Capital Structure, Profitability and Firm Value: Panel Evidence of Listed Firms in Kenya. Munich Personal RePEc Archive, (57116).

Kouki, M., Elkhaldi, A., Atri, H., \& Souid, S. (2011). Does Corporate Governance Constrain Earnings Management? Evidence from U . S . Firms. European Journal of Economics, Finance and Administrative Sciences, 35, 58-71.

Moeljadi. (2014). Theoretical Study on Public Manufacturing Firms in Indonesia. International Journal of Business and Management Invention, 3(2), 6-15. 
Novari, P. M., \& Lestari, P. V. (2016). Pengaruh Ukuran Perusahaan, Leverage, dan Profitabilitas Terhadap Nilai Perusahaan Pada Sektor Properti dan Real Estate. E-Jurnal Manajemen Unud, 5(9), 5671-5694.

Obradovich, J., \& Gill, A. (2012). The Impact of Corporate Governance and Financial Leverage on the Value of American Firms. International Research Journal of Finance and Economics, (91).

Ogolmagai, N. (2013). Leverage Pengaruhnya Terhadap Nilai Perusahaan pada Industri Manufaktur Yang Go Public di Indonesia. Jurnal EMBA, 1(3), 8189.

Pramana, I. G. N. A. D., \& Mustanda, I. K. (2016). Pengaruh Profitabilitas dan Size Terhadap Nilai Perusahaan Dengan CSR Sebagai Variabel Pemoderasi. E-Jurnal Manajemen Unud, 5(1), 561-594.

Prastuti, N. K. R., \& Sudiartha, I. G. M. (2016). Pengaruh Struktur Modal, Kebijakan Dividen, dan Ukuran Perusahaan Terhadap Nilai Perusahaan Pada Perusahaan Manufaktur. E-Jurnal Manajemen Universitas Udayana, 5(3). Retrieved from http://ojs.unud.ac.id/index.php/Manajemen/article/view/16540

Pratama, I. G. B. A., \& Wiksuana, I. G. B. (2016). Pengaruh Ukuran Perusahaan dan Leverage Terhadap Nilai Perusahaan Dengan Profitabilitas Sebagai Variabel Mediasi. E-Jurnal Manajemen Unud, 5(2), 1338-1367.

Pratiska, N. G. A. P. S. (2012). Pengaruh Ios, Leverage dan Dividend Yield Terhadap Profitabilitas dan Nilai Perusahaan Sektor Manufaktur di BEI. Jurnal Magister Manajemen Universitas Udayana, 2(3), 147-174.

Pratiwi, N. P. Y., Yudiaatmaja, F., \& Suwendra, W. (2016). Pengaruh Struktur Modal dan Ukuran Perusahaan Terhadap Nilai Perusahaan. Jurusan Manajemen, 4.

Priyastuty, H. (2014). Analisis Pengaruh Ukuran Perusahaan, Leverage dan Profitabilitas Terhadap Nilai Perusahaan. Universitas Brawijaya.

Putu, N. N. G. M., Moeljadi, Djumahir, \& Djazuli, A. (2014). Factors Affecting Firms Value of Indonesia Public Manufacturing Firms. International Journal of Business and Management Invention, 3(2), 35-44. Retrieved from www.ijbmi.org

Ramadan, I. Z. (2015). Leverage and the Jordanian Firms ' Value: Empirical Evidence. International Journal of Economics and Finance, 7(4), 75-81. https://doi.org/10.5539/ijef.v7n4p75 
Rasyid, A., Mahfudnurnajamuddin, Mas'sud, M., \& Su'un, M. (2015). Effect of Ownership Structure, Company Size and Prifitability on Dividend Policy and Manufacturing Company's Value in Indonesia Stock Exchange. Australian Journal of Basic and Applied Sciences, 9(20), 618-624.

Riyanto, B. (2010). Dasar-dasar Pembelajaran Perusahaan (4th ed.). Yogyakarta: BPFE.

Rumondor, R., Mangantar, M., \& Sumarauw, J. S. B. (2015). Pengaruh Struktur Modal, Ukuran Perusahaan dan Risiko Perusahaan Terhadap Nilai Perusahaan Pada Sub Sektor Plastik dan Pengemasan di BEI. Jurnal EMBA, 3(3), 159-169.

Sari, P. I. P., \& Abundanti, N. (2014). Pengaruh Pertumbuhan Perusahaan dan Leverage Terhadap Profitabilitas dan Nilai Perusahaan. E-Jurnal Manajemen Unud, 3(5), 1427-1441.

Sugiyono. (2014). Metode Penelitian Bisnis. Bandung: CV. Alfabeta.

Suharli, M. (2006). Studi Empiris Terhadap Faktor yang Memengaruhi Nilai Perusahaan pada Perusahaan Go Public di Indonesia. Jurnal Manjemen Akuntansi, 6(1).

Sujoko, \& Soebiantoro, U. (2007). Pengaruh Struktur Kepemilikan Saham, Leverage, Faktor Intern Dan Faktor Ekstern Terhadap Nilai Perusahaan ( Studi empirik pada perusahaan manufaktur dan non manufaktur di Bursa Efek Jakarta ). Jurnal Manajemen Dan Kewirausahaan, 9(1), 41-48.

Weston, \& Copeland. (1992). Managerial Finance (9th ed.). The Dryden Pres. Orlando Florida.

Wiagustini, N. L. P. (2014). Dasar-dasar Manajemen Keuangan (1st ed.). Denpasar: Udayana Press.

Wijaya, B. I., \& Sedana, I. B. P. (2015). Pengaruh Profitabilitas Terhadap Nilai Perusahaan (Kebijakan Deviden dan Kesempatan Investasi Sebagai Variabel Mediasi). E-Jurnal Manajemen Unud, 4(12), 4477-4500. 